\title{
Gradient of algal and cyanobacterial assemblages in a temporary lake with melting water at Solorina Valley, James Ross Island, Antarctica
}

\author{
Kateřina Skácelová*, Miloš Barták
}

Department of Plant Physiology and Anatomy, Institute of Experimental Biology, Faculty of Science, Masaryk University, Kamenice 5, 62500 Brno, Czech Republic

\begin{abstract}
The aim of presented study is to contribute to species list of algae, cyanobacteria and diatoms from moist localities of James Ross Island, Solorina Valley $\left(63^{\circ} 53^{\prime} \mathrm{S}, 57^{\circ} 48^{\prime} \mathrm{W}\right)$ in particular. In 2012, samples of microbiological mats were taken from a bottom of shallow depression close to a seashore line. The sampling site has been filled with melting water from glacier for some weeks preceding the collection. On collection date, however it was dried out. The samples were analysed using optical microscopy approach after the transport of samples to Czech Republic (Masaryk University, Brno). Algal and cyanobacterial taxa forming the microbiological mats were determined according to their morphological characteristics and the frequencies of individual taxa occurrence evaluated. Species richness differed between individual sampling sites located across a shallow depression suggesting an ecological role of duration of stagnant water for biodiversity in temporary freshwater ponds. Altogether, 37 algal and cyanobacterial taxa were found. While 23 taxa present in the centre of the depression, only 10 taxa were found close to the margin where the dry period was the longest.
\end{abstract}

Key words: James Ross Island, mats, temporary pond, algae, cyanobacteria

DOI: $10.5817 / \mathrm{CPR} 2014-2-19$

\section{Introduction}

Within last decades, species diversity in microbiological mats from Antarctic habitats represents an important aspect of field and laboratory studies. It is because endemism of Antarctic autotrophic microorganisms, cyanobacteria in particular, is still an open question (Vincent 2000). That is why a great number of studies use molecular biology tools to determine species forming microbiological mats in different Antarctic habitats, such as e.g. dry valleys lakes (Taton et al. 2003).

Received November 1, 2014, accepted December 30, 2014.

*Corresponding author: Kateřina Skácelová <katka.skacel@volny.cz>

Acknowledgements: The authors thank to the infrastructure of the CzechPolar for providing facilities necessary for sample collection, their storage and handling before microscopic study. 
Terrestrial freshwater algae and cyanobacteria are quite abundant in maritime Antarctica, especially along the South Shetland Islands and western coast of Trinity peninsula. James Ross Island, located east of the Antarctic peninsula, however, represents a location typical by both maritime and continental climate. Therefore, species typical for maritime Antarctica could be expected to a less extent than on the western coast of the Antarctic peninsula. Species richness of algae and cyanobacteria has been studied at the James Ross Island since 1990ies by e.g. Elster et al. 2013, Komárek et Elster 2008, Komárek et Komárek 2010, Komárek et al. 2008, 2012, 2014. Specifically for diatoms, numerous studies has been devoted to their taxonomy and occurrence at the James Ross Island (e.g. Kopalová et al. 2002, 2013, Van de Vijver et al. 2011, Zidarova et al. 2014). In these studies, collection sites were mainly lakes, streams, seepages, and wet rock surfaces. Less attention has been devoted to temporary freshwater ponds.

Temporary freshwater ponds represent quite frequent niche in Arctic (e.g. Elster et al. 1997) and Antarctic regions during

\section{Material and Methods}

\section{Sampling site description}

Samples of microbiological mats were collected from Solorina Valley $\left(63^{\circ} 53^{\prime} \mathrm{S}\right.$, $57^{\circ} 48^{\prime} \mathrm{W}, 60 \mathrm{~m}$ a.s.1.), James Ross Island, Antarctica - see Fig. 1. Sampling site was located $150 \mathrm{~m}$ from a seashore. It was a shallow depression that had been filled with stagnant water for some weeks preceding the collection. On collection date, however, it was dried out. The sample summer season. Typically, they hold liquid water for a few weeks or months. Different aspects of biology of such ponds has been studied covering e.g. freshwater fauna biodiversity (Filgueiras et al. 2007), predation of pelagic microorganisms (Bertilsson et al. 2003), cyanobacterial toxicity (Hitzfeld et al. 2000, Kleinteich et al. 2014) etc. Dynamics of freshwater algae biodiversity in temporary polar ponds has been studied in Northern hemisphere (e.g. Jang-Seu et al. 2006), however, only few studies are available from Antarctica (Jungblut et al. 2005). In spite of numerous studies of diatoms and cyanobacteria that have been taken at different localities of James Ross Island (mainly seepages, streams, ponds and lakes), Solorina Valley has not yet been investigated. Therefore, we focused on a small-area temporary pond from the above-specified site to describe species richness and differences in community composition as related to the radial gradient from pond centre to the margin. We hypothesized that differences in species composition would be found and related to the length of the period for which water was available before the pond got dry.

No. 1 were taken from a margin part of the former shallow pond followed by the other ones (No. 2 to 5) taken at regular intervals towards the centre of depression (see Fig. 2). The samples were then delivered to J. G. Mendel Czech Antarctic station, where dried under natural conditions and stored in dried state in a refrigerator $\left(5^{\circ} \mathrm{C}\right)$. 

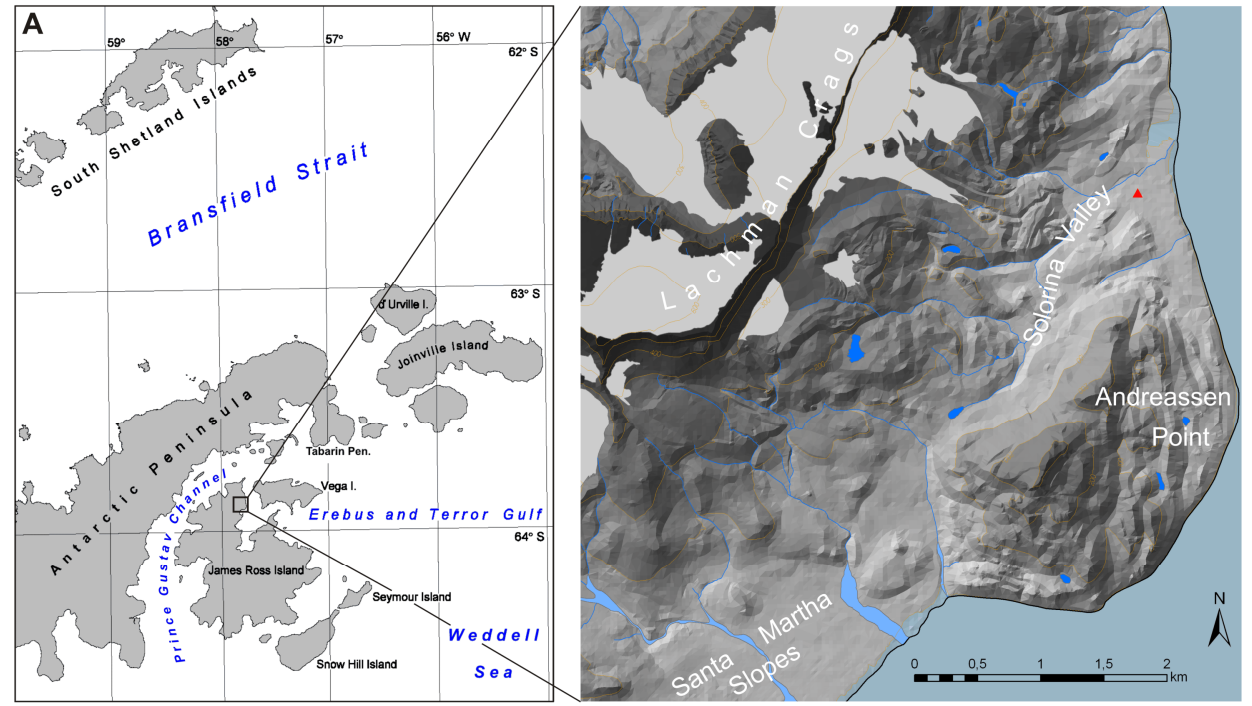

Fig. 1. Map of the northern part James Ross Island. Red point indicates the studied area. Adopted from Czech Geological Survey, 2009.

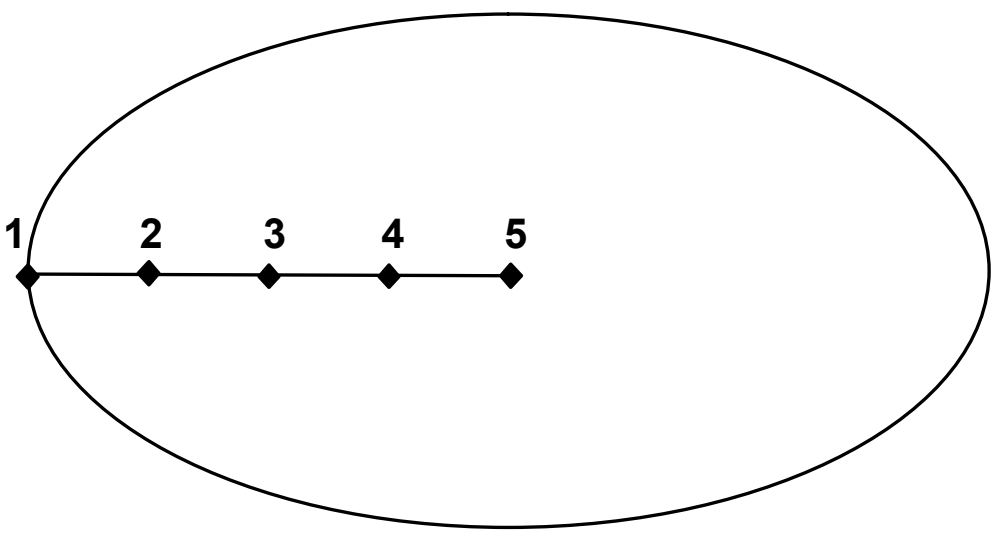

Fig. 2. Scheme of temporary pond at Solorina Valley with marked sampling sites from a margin part (No. 1) to the centre (No. 5).

\section{Optical microscopy}

Dried samples of microbiological mats were transported to Brno (Czech Republic) for analysis. After transfer, the samples were rewetted and biodiversity of autotrophic organisms determined as dependent on the distance of samples from depression centre. We hypothesized that biodiversity as well as abundance of the species would be dependent on the time of liquid water availability which was longest in the depression centre. 
Algal and cyanobacterial species were observed in microbiological mats from individual sampling sites (No. 1 to 5). Each of crust were (re)hydrated and analysed by an optical microscopy (Olympus BX50, Japan). Digital photographs of algal and cyanobacterial species found in the mats were taken by Sony SLT-A35. Throughout all samples, more than 1000 microphotographs were taken and analysed, so that individual mat-forming species could be distinguished. Morphologic approach was used to determine particular algal and cyanobacterial species. Relative frequencies of species were calculated for each sample.

\section{Results}

In all studied samples from Solorina Valley are cyanobacteria predominating taxonomic group. During this research, living cells of Bacillariophyceae were not present, only their single empty frustules in microbiological mats from sampling sites number 2, 3, 4 and 5. Because of this fact, we assume the studied site has been colonised by them but they were not found on soil surface in a dry period which took place here at the time of collection (being hidden in deeper soil layers).

In the examined samples of microbiological mats, total number of 37 algal and cyanobacterial taxa were found. Number of species, however, differed between sampling sites (see Table 1). The highest

\section{Discussion}

Our results indicate that the community structure of microbiological mats differed between sampling sites (from water holding central part of the temporary pond towards marginal part lacking water for a longer period during austral summer season). This could be documented both for total number of taxa found in central (23) compared to marginal part (10), as well as for specificity of species composition. While quantity of Streptophytes and Bacillariophytes was found to increase toward the central part, they were not found in the marginal part.

biodiversity was found in the central part of the depression (23) and species richness declined toward to margins. Sampling site No. 1 was distinctly dominated with cyanobacterium Microcoleus sp. morphotype 1 (Fig. 3A) which has a strong sheath protecting against desiccations. Following samples (sites No. 2 and No. 3, closer toward the centre) were dominated with Nostoc sp. (Figs. 3B, F) and Leptolyngbya sp. (thick grey filaments with granulations). At site No. 4 were the most abundant some species of Xanthophyta (Fig. 3G) and cyanobacterium Leptolyngbya erebi. L. erebi dominated also in central part of the locality (site No. 5).
Cyanobacteria were present in all sampling sites. In the central part, the most abundant group of cyanobacteria were Oscillatoriales (Figs. 3A, D), however, Nostocales (e.g. Hydrocoryne quesadae Fig. 3C) and Chroococcales (e.g. Coelomoron chroococcoideum - Fig. $3 \mathrm{H}$ ) also occurred there. In the marginal part, cyanobacterial taxa with mucilaginous envelopes (e.g. Nostoc sp. - Figs. 3B, F, Microcoleus sp. morphotype 1 - Fig. 3A) or with encrusted sheaths (Calothrix sp. Fig. 3E) were more abundant. 


\begin{tabular}{|c|c|c|c|c|c|}
\hline & site 1 & site 2 & site 3 & site 4 & site 5 \\
\hline \multicolumn{6}{|l|}{ Cyanobacteria } \\
\hline Aphanocapsa sp. & + & & & & + \\
\hline Calothrix sp. & ++ & + & + & & \\
\hline $\begin{array}{l}\text { Coelomoron chroococcoideum (West } \\
\text { \& West) Komárek } 2013\end{array}$ & & + & + & + & ++ \\
\hline $\begin{array}{l}\text { Dactylothamnos antarcticus Fiore, } \\
\text { Genuário \& Komárek } 2014\end{array}$ & + & + & + & + & + \\
\hline Geitlerinema sp. & & & + & ++ & \\
\hline $\begin{array}{l}\text { Hassalia andreassenii Komárek, } \\
\text { Nedbalová \& Hauer } 2012\end{array}$ & + & & + & & \\
\hline $\begin{array}{l}\text { Hydrocoryne quesadae Komárek \& } \\
\text { Genuário } 2014\end{array}$ & + & ++ & + & ++ & ++ \\
\hline Chroococcus sp. & & & + & & \\
\hline $\begin{array}{l}\text { Leptolyngbya erebi (West \& West) } \\
\text { Anagnostidis \& Komárek } 1988\end{array}$ & ++ & ++ & + & +++ & +++ \\
\hline Leptolyngbya $\mathrm{sp}$. & & +++ & +++ & & \\
\hline Microcoleus sp. (morphotype 1) & +++ & + & + & & \\
\hline Microcoleus sp. (morphotype 2) & & ++ & & & \\
\hline Nodularia quadrata Fritsch 1929 & & + & & + & ++ \\
\hline Nostoc sp. & ++ & +++ & +++ & + & \\
\hline Oscillatoria sp. (morphotype 1) & + & & ++ & & \\
\hline Oscillatoria sp. (morphotype 2) & & + & & & \\
\hline Oscillatoria sp. (morphotype 3) & & & +++ & ++ & \\
\hline Phormidium sp. (morphotype 1) & & ++ & & & \\
\hline Phormidium sp. (morphotype 2) & & + & + & & ++ \\
\hline Phormidium sp. (morphotype 3) & & & ++ & ++ & ++ \\
\hline Pseudanabaena sp. & & & & & ++ \\
\hline \multicolumn{6}{|l|}{ Chlorophyta } \\
\hline Ulothrix sp. & & + & + & & \\
\hline \multicolumn{6}{|l|}{ Streptophyta } \\
\hline Actinotaenium sp. & & ++ & + & & + \\
\hline Cosmarium sp. & & & + & & \\
\hline Klebsormidium sp. & & & & + & + \\
\hline Staurastrum sp. & & & & + & + \\
\hline Zygnema sp. & & & & + & + \\
\hline \multicolumn{6}{|l|}{ Bacillariophyta } \\
\hline Hantzschia sp. & & & + & + & + \\
\hline Luticola sp. & & & & + & \\
\hline Neidium sp. & & & & + & + \\
\hline Nitzschia sp. & & & & & + \\
\hline Stauroneis sp. & & & & + & \\
\hline Chlorophyta (spherical cells) & & + & + & + & + \\
\hline Xanthophyta & + & + & + & +++ & + \\
\hline Phormidiales (hormogonia) & & & & + & ++ \\
\hline coccal green elipsoid cells & & & & + & + \\
\hline other pennate diatoms & & + & + & & \\
\hline tiny green spherical cells & & & + & ++ & + \\
\hline
\end{tabular}

Table 1. Occurrence of algal and cyanobacterial taxa in sampling sites of the temporary pond (Solorina Valley, Antarctica). +++ frequent taxa, ++ medium taxa, + rare occurring taxa. 

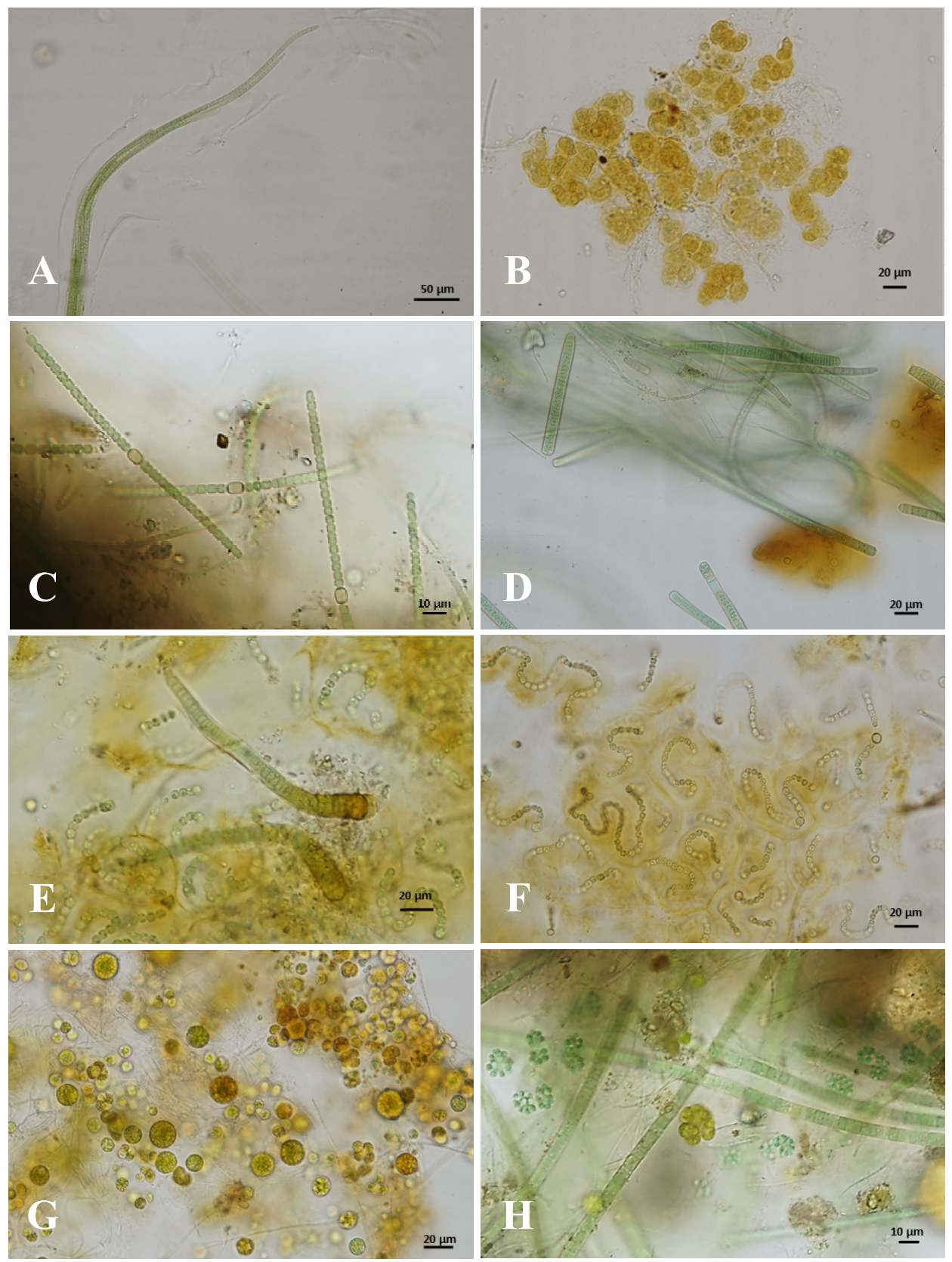

Fig. 3. Cyanobacteria and algae of James Ross Island - Solorina Valley. A - Microcoleus sp. (morphotype 1) from sampling site No. 1, B - initial stage of Nostoc sp. (site No. 1), C Hydrocoryne quesadae (site No. 2), D - Oscillatoriales (site No. 3), E-Calothrix sp. (site No. 3), F - Nostoc sp. (site No. 3), G - Eustigmatophyceae (site No. 4), H - Coelomoron chroococcoideum (site No. 5). Photos by K. Skácelová. 
Our study represents a contribution to biodiversity of freshwater algae, cyanobacteria and diatoms on the James Ross Island. Within last few years, several sites have been sampled on the island and numerous taxa was determined (see e.g. Skácelová et al. 2013). In some selected species, photosynthetic parameters were studied under laboratory conditions in response to light, temperature (Barták et al. 2013), and osmotic stress (Vilumbrales et al. 2013). However, research on biodiversity is far from being completed because of tens to hundreds of sites that have never been sampled at deglaciated part of James Ross Island.

\section{References}

Bertilsson, S., Hansson, L.-A., Graneli, W. and Philibert, A. (2003): Size-selective predation on pelagic microorganisms in Arctic freshwaters. Journal of Planktonic Research, 25: 621-632.

Barták, M., Váczi, P., Skácelová, K., NÝvlt, D., Miguel Vilumbrales, D., Sehnal, L., TrnkovÁ, K. and HAzDrovÁ, J. (2013): Photosynthetic processes in two algal species from Antarctic lakes in response to stress factors. In: 54. pracovní konference české algologické společnosti, 16.-18. září 2013, Třeboň.

Elster, J., KomáreK, J. and NedbalovÁ, L. (2013): Biodiverzita řas a sinic. In: P. Prošek (ed.): Antarktida. Academia Publishing House, Prague, Czech Republic. pp. 303-311.

Elster, J., Svoboda, J., Komárek, J. and Marvan, P. (1997): Algal and cyanoprocaryote communities in a glacial stream, Sverdrup Pass, $79^{\circ} \mathrm{N}$, Central Ellesmere Island, Canada. Algological Studies, 85: 57-93.

Filgueiras, V. L., Campos, L. S., Lavrado, H. P., Frensel, R., and Pollery, R. C. G. (2007): Vertical distribution of macrobenthic infauna from the shallow sublittoral zone of Admiralty Bay, King George Island, Antarctica. Polar Biology 30: 1439-1447.

Hitzfeld B.C., Lampert C.S., Spaeth N., Mountfort D., Kaspar H. and Dietrich D.R. (2000): Toxin production in cyanobacterial mats from ponds on the McMurdo Ice Shelf, Antarctica. Toxicon, 38: 1731-1748.

Jang-Seu, K., Sung-Ho, K., Sung-Won, J., Bum-Soo, P. and Myung-Soo, H. (2006): A study on the freshwater algal flora occurring in temporary ponds around the Dasan Arctic Station, NyAlesund (Norway), and the molecular characteristics of Chlamydomonas 18S rDNA. Ocean and Polar Research, 28: 107-117.

Jungblut, A. D., Hawes, I., Mountfort, D., Hitzfeld, B., Dietrich, D. R., Burns, B. P. and NeIlan, B. A. (2005): Diversity within cyanobacterial mat communities in variable salinity meltwater ponds of McMurdo Ice Shelf, Antarctica. Environmental Microbiology, 7: 519-29.

Kleinteich, J., Hildebrand, F., Wood, S. A., Cirés, S., Agha, R., Quesada, A., Pearce, D. A., Convey, P., Küpper, F. C. and Dietrich, D. R. (2014): Diversity of toxin and non-toxin containing cyanobacterial mats of meltwater ponds on the Antarctic Peninsula: a pyrosequencing approach. Antarctic Science, 26: 521-532.

KomÁreK, J., Elster, J. (2008): Ecological background of cyanobacterial assemblages of the northern part of James Ross Island, Antarctica. Polish Polar Research, 29: 17-32.

KomÁreK, J., Elster, J. and KomÁREK, O. (2008): Diversity of the cyanobacterial microflora of the northern part of James Ross Island, NW Weddell Sea, Antarctica. Polar Biology, 31: 853865 .

KomÁreK, O., KomÁreK, J. (2010): Diversity and ecology of cyanobacterial microflora of Antarctic seepage habitats: Comparison of King George Island, Shetland Islands, and James Ross Island, NW Weddell Sea, Antarctica. In: J. Seckbach, A. Oren, (eds.): Microbial Mats. Modern and Ancient Microorganisms in Stratified Systems. Springer, pp. 517-538.

Komárek, J., GenuÁrio, D. B., Fiore, M. F. and Elster, J. (2014): Heterocytous cyanobacteria of the Ulu Peninsula, James Ross Island, Antarctica. Polar Biology,doi: 10.1007/s00300-0141609-4. 
Komárek, J., NedbalovÁ, L. and Hauer, T. (2012): Phylogenetic position and taxonomy of three heterocytous cyanobacteria dominating the littoral of deglaciated lakes, James Ross Island, Antarctica. Polar Biology, 35: 759-774.

Kopalová, K., Nedbalová, L., NÝvlt, D., Elster, J. and Van de Vijver, B. (2013): Diversity, ecology and biogeography of the freshwater diatom communities from Ulu Peninsula (James Ross Island, NE Antarctic Peninsula). Polar Biology, 36: 933-948.

Kopalová, K., Veselá, J., Elster, J., Nedbalová, L., Komárek, J. and Van de Vijver, B. (2012): Benthic diatoms (Bacillariophyta) from seepages and streams on James Ross Island (NW Weddell Sea, Antarctica). Plant Ecology and Evolution, 145: 1-19.

SkÁcelová, K., BARTÁK, M., Coufalík, P., NÝVlt, D. and TrnkovÁ, K. (2013): Biodiversity of freshwater algae and cyanobacteria on deglaciated northern part of James Ross Island, Antarctica. A preliminary study. Czech Polar Reports, 3: 93-106.

Smith, R. I. L., Ovstedal, D. O. (1994): Solorina spongiosa in Antarctica. An extremely disjunct bipolar lichen. Lichenologist, 26: 209-213.

Taton, A., Grubisic, S., Brambilla, E., De Wit, R. and Wilmotte, A. (2003): Cyanobacterial diversity in natural and artificial microbial mats of Lake Fryxell (McMurdo Dry Valleys, Antarctica): a morphological and molecular approach. Applied Environmental Microbiology, 69: 5157-5169.

VAN DE ViJver, B., Zidarova, R. and DE HAAN, M. (2011): Four new Luticola taxa (Bacillariophyta) from the South Shetland Islands and James Ross Island (Maritime Antarctic Region). Nova Hedwigia, 92: 137-158.

Vilumbrales, M. D., SkÁcelová, K. and BARTÁK, M. (2013): Sensitivity of Antarctic freshwater algae to salt stress assessed by fast chlorophyll fluorescence transient. Czech Polar Reports, 3: 163-172.

VINCENT, W. F. (2000): Evolutionary origins of Antarctic microbiota: invasion, selection and endemism. Antarctic Science, 12: 374-385.

Zidarova, R., KopalovÁ, K. and VAN DE ViJver, B. (2014): The genus Stauroneis (Bacillariophyta) from the South Shetland Islands and James Ross Island (Antarctica). Fottea, 14: 201-207.

\section{Other sources}

Czech Geological Survey. 2009. James Ross Island - Northern Part. Topographic map

$1: 25$ 000. First edition. Praha, Czech Geological Survey. ISBN 978-80-7075-734-5. 